\title{
LIMITES E DESAFIOS DA GESTÃO DEMOCRÁTICA NA ESCOLA PÚBLICA: um estudo a partir do sertão alagoano
}

\author{
Luciene Amaral da Silva ${ }^{1}$ \\ Inalda Maria dos Santos²
}

\section{RESUMO}

O artigo é parte da dissertação de mestrado do Programa de Pós-Graduação em Educação da Universidade Federal de Alagoas, que teve por objetivo analisar os motivos que levaram três escolas da $6^{a}$ Coordenadoria Regional de Educação pertencente à Secretaria de Estado da Educação de Alagoas a submeterem-se à indicação de professores para o provimento da função de gestor escolar dentro de um processo de gestão democrática implantado na rede pública estadual de ensino desde 1999. O recorte temporal em que se baseou a pesquisa foi a eleição para gestor escolar no ano de 2013. Usou-se o método quantitativo qualitativo, com entrevistas semiestruturadas como instrumento de coleta de dados. Partindo do entendimento de que a gestão democrática é um processo de participação consciente dos sujeitos para que a democracia seja de fato exercitada em âmbito escolar, a pesquisa buscou em diversos autores como Paro (2001; 2003), Dourado (1990; 1998), Lück (2005), dentre outros, contextualizar a gestão democrática dentro do processo de redemocratização do país e apontar elementos como interesses pessoais, legislação defasada, más condições de trabalho dos professores da rede estadual de educação, para compreensão do fenômeno da indicação que acontece no Estado de Alagoas.

Palavras-chave: Política Educacional. Gestão Democrática. Eleição de Gestor em Alagoas.

\section{LIMITS AND CHALLENGES OF DEMOCRATIC MANAGEMENTE IN THE PUBLIC SHOOL: a study fron the Alagoan sertão}

\begin{abstract}
The article is part of the master's dissertation of the Graduate Program in Education of the Federal University of Alagoas, whose objective was to analyze the reasons that led three schools of the 6th Regional Coordination of Education belonging to the State Secretariat of Education of Alagoas to be To submit to the appointment of

\footnotetext{
1 Doutoranda em Educação - PPGE/UFAL. Professora da Educação Básica da rede estadual de ensino de Alagoas. E-mail: cieneamaral@hotmail.com

2 Doutorado em Educação. Professora do Centro de Educação - PPGE/CEDU/UFAL. E-mail: inaldasantos@vol.com.br
} 
teachers to fill the role of school manager within a process of democratic management implemented in the state public school system since 1999. The time frame on which the research was based was the election for school manager in the year 2013. The qualitative quantitative method was used, with semi-structured interviews as a data collection instrument. Based on the understanding that democratic management is a process of conscious participation of the subjects in order for democracy to be effectively exercised in a school environment, research has sought in several authors such as Paro $(2001,2003)$, Dourado $(1990,1998)$, Lück (2005), among others, to contextualize democratic management within the process of redemocratization of the country and to point out elements such as personal interests, lagged legislation, poor working conditions of the teachers of the state education network, to understand the phenomenon of the indication that happens in the state Of Alagoas.

Keywords: Educational Policy. Democratic Management. Election Alagoas Manager.

\section{LÍMITES Y DESAFíOS DE LA GESTIÓN DEMOCRÁTICA EN LA ESCUELA PÚBLICA: un}

\section{estudio del sertón alagoano}

\section{RESUMEN}

El artículo es parte de la disertación de maestría del Programa de Postgrado en Educación de la Universidad Federal de Alagoas, que tuvo por objetivo analizar los motivos que llevaran a tres escuelas de la $6^{a}$ Coordinadora Regional de Educación perteneciente a la Secretaría de Estado en Educación de Alagoas, someter a la indicación de profesores para la provisión de la función de gestor escolar dentro de un proceso de gestión democrática implantado en la red pública estatal de enseñanza desde 1999. El recorte temporal en que se basó la encuesta fue la elección para gestor escolar en el año 2013. Se utilizó el método cuantitativo cualitativo, con entrevistas semiestructuradas como instrumento de recolección de datos. A partir del entedimiento de que la gestión democrática es un proceso de participación consciente de los sujetos para que la democracia sea de hecho ejercitada en ámbito escolar, la investigación buscó en diversos autores como Paro( 2001;2003), Dourado (1990;1998), Lück (2005), entre otros, contextualizar la gestión democrática dentro del proceso de redemocratización del país y apuntar elementos como intereses personales, legislación defasada, malas condiciones de trabajo de los profesores de la red estadual de educación, para comprender el fenómeno de la indicación que ocurre en el estado de Alagoas.

Palabras clave: Política Educativa. Gestión Democrática. Elección de Gestor en Alagoas.

\section{INTRODUÇÃO}

A problemática em torno dos mecanismos de democratização da educação constituiu o foco central do trabalho de investigação realizado 
no âmbito do Mestrado em Educação da Universidade Federal de Alagoas, em que se buscou analisar os motivos que levaram três escolas da $6^{a}$ Coordenadoria Regional de Educação pertencente à Secretaria de Estado da Educação de Alagoas, a se submeterem à indicação de professores para o provimento da função de gestor escolar dentro de um processo de gestão democrática implantado na rede pública estadual de ensino desde 1999.

O recorte temporal em que se baseou a pesquisa foi a eleição para gestor escolar no ano de 2013. Usou-se o método quantitativo qualitativo, com entrevistas semiestruturadas como instrumento de coleta de dados. Partindo do entendimento de que a gestão democrática é um processo de participação consciente dos sujeitos para que a democracia seja de fato exercitada em âmbito escolar. Para tanto, a pesquisa buscou em diversos autores como Paro, (2001; 2003); Dourado, (1990; 1998); Lück, (2005); dentre outros, contextualizar a gestão democrática dentro do processo de redemocratização do país.

O processo de gestão democrática compreende desde a eleição do diretor - "um procedimento importante, mas não assegura em si a efetiva democratização dos estabelecimentos de ensino" (LIMA apud DIÓGENES; PRADO, 2011, p. 157), passando pela elaboração/vivência do projeto político pedagógico, a participação/presença da comunidade nas instâncias da escola e a eleição do Conselho Escolar, como espaço de representação da comunidade educacional - um elemento necessário para a proposta de melhoria da qualidade da educação.

No entanto, mesmo diante do cenário educacional atual em que a gestão escolar democrática tenta superar as práticas de autoritarismo dentro da escola (DOURADO, 1998), os sujeitos que fazem parte desse processo encontram limites e dificuldades de mudança. Com isso, a cultura escola que permeia as relações dentro da escola precisa atingir um nível de maturidade política, visto que ainda sofre com as raízes autoritárias implantadas no decorrer da história. 
A participação no espaço escolar acontece, na maioria das vezes, a passos lentos. A responsabilidade da escola ainda recai na figura do gestor, "[...] à medida que a comunidade escolar, ao delegar seu voto, delega também ao diretor, os erros ou acertos, o autoritarismo ou a democratização das relações intra-escolares" (DOURADO, 1990 apud PARO, 2003, p.101), desse modo, a gestão da escola torna-se um processo solitário para o gestor.

Considerando esse cenário, na realidade das escolas da rede pública de ensino de Alagoas surge um fenômeno contrário à luta pela democratização da gestão da escola que é a indicação de professores para provimento do cargo de gestor escolar, dentro de um processo de gestão democrática implantado no estado desde 1999 com a modalidade de eleição direta e secreta para escolha do gestor, que constituiu foco de investigação apresentada a seguir.

\section{A ELEIÇÃO DE GESTOR NA REDE ESTADUAL DE ENSINO DE ALAGOAS PARA A GESTÃO 2013/2015}

As condições ofertadas nas escolas da rede pública estadual de Alagoas não se tornam atrativas para que professores candidatem-se à função de gestor escolar.

Costa (1931, p. 11) afirma que, desde 1896, muito tempo foi perdido com reformas educacionais que não tinham nenhum efeito sobre a melhoria da educação, "enquanto tivermos instrução sem escola, escola sem mobília e material apropriado, desprovidas de todos os outros meios práticos, o ensino não será uma realidade".

É importante perceber que as escolas públicas alagoanas, desde o período da colonização, sempre foram alvo do clientelismo, vindo de apadrinhamentos políticos, os indicados a gestores gerenciavam suas ações de acordo com o plano de governo de quem colocava à frente das escolas.

As decisões eram tomadas de forma hierarquizada e os recursos da escola centralizados na gestão, com o propósito de garantir a continuação 
de mandatos políticos, em que o diretor da escola atribuía a si mesmo o papel de delator para garantir fidelidade às regras estabelecidas pela gestão política em vigor.

Na realidade atual de Alagoas, em relação ao quadro de professores e demais funcionários nas escolas, a situação é mais agravante. O quadro de professores efetivos do estado, bem reduzido, é complementado, com professores contratados pela rede estadual para tentar suprir carência. Muitos alunos da rede estadual concluem seus cursos com débito de disciplinas porque não tiveram professor para determinadas disciplinas. Professores são contratados com baixíssimos salários. A partir dessa realidade, surgem, então, cursos de férias a fim de suprir tais deficiências.

Quanto aos demais funcionários lotados nas escolas, há unidades escolares funcionando com ausência de funcionários administrativos, levando, muitas vezes, gestores e coordenadores pedagógicos a desempenharem funções que não lhes competem para que a escola funcione e o aluno tenha aula.

Diante da realidade, a função de gestor escolar na rede estadual de Alagoas passa por sérias dificuldades pelo fato de haver indicação dentro de um processo democrático, entender porque isso ocorre, foi o que buscamos investigar. A eleição para o provimento da função de gestor escolar das escolas da rede pública estadual de ensino para o biênio 2013/2015, recorte temporal da análise desse estudo, acentuou, mais uma vez, a questão da indicação que está presente no estado de Alagoas.

Segundo a Secretaria de Estado da Educação e do Esporte, existe uma quantidade significativa de gestores indicados no período de 2013 , fato que não poderia existir, visto que a gestão democrática foi implantada na rede a partir de 1999.

De acordo com dados da Secretaria de Estado da Educação (GEGEC/SEE/AL, 2014), mais de 10\% dos diretores eleitos em 2013 foram indicados. 
O gráfico abaixo apresenta o percentual de gestores indicados no último processo de eleição ocorrido no estado de Alagoas no ano de 2013:

Gráfico 1: Quantidades de diretores eleitos e indicados em Alagoas em 2013

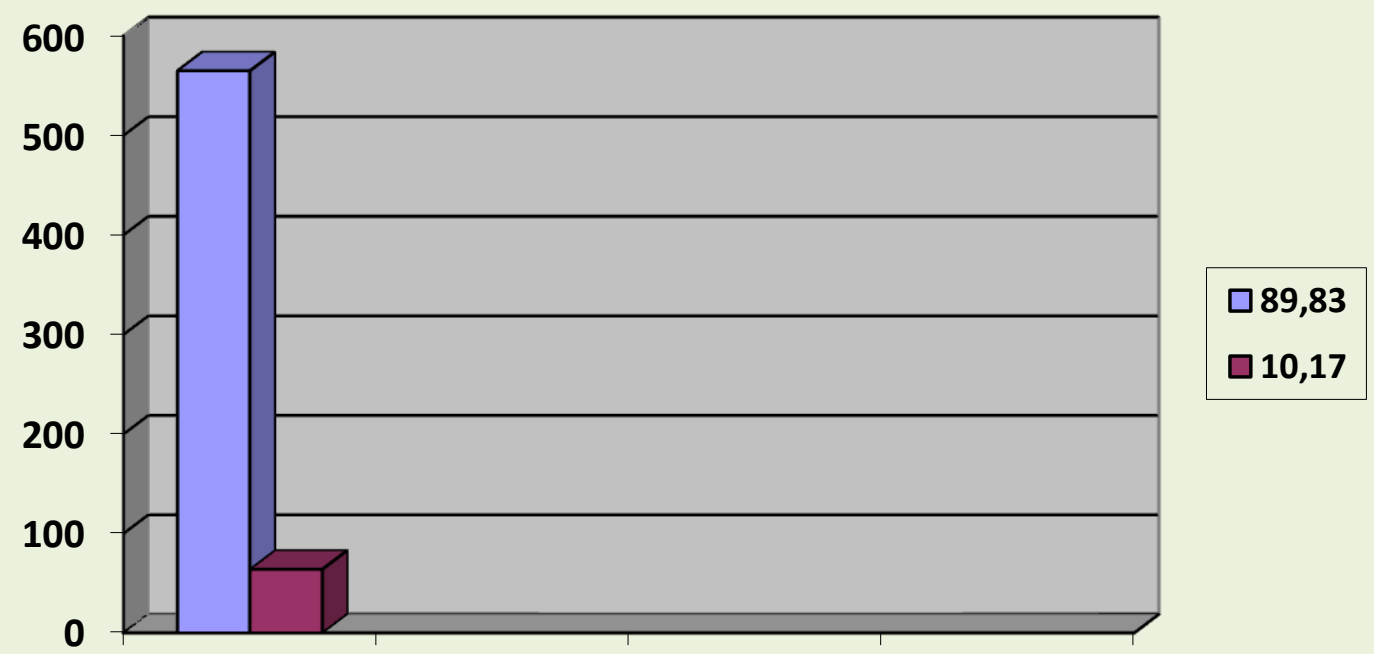

Fonte: Gerência de Gestão Compartilhada - GEGEC/SEE/AL, 2014

Quanto à quantidade de Coordenadorias em que houve indicação o número é alarmante. Das 15 (quinze) Coordenadorias Regionais de Educação, apenas 3 (três) não passaram pela indicação como provimento da função de gestor escolar, conforme quadro abaixo:

Quadro 1: Quantidade de professores eleitos e indicados por CRE em 2013

\begin{tabular}{|c|c|c|c|}
\hline CRE & $\begin{array}{c}\text { TOTAL DE } \\
\text { GESTORES }\end{array}$ & GESTORES ELEITOS & $\begin{array}{c}\text { GESTORES } \\
\text { INDICADOS }\end{array}$ \\
\hline $1^{a}$ & 59 & 52 & 7 \\
\hline $2^{a}$ & 31 & 28 & 3 \\
\hline $3^{a}$ & 54 & 53 & 1 \\
\hline $4^{a}$ & 21 & 21 & 0 \\
\hline $5^{a}$ & 72 & 70 & 2 \\
\hline $6^{a}$ & 37 & 34 & 3 \\
\hline $7^{a}$ & 29 & 25 & 4 \\
\hline $8^{a}$ & 19 & 16 & 3 \\
\hline $9^{a}$ & 33 & 22 & 11 \\
\hline $10^{a}$ & 29 & 29 & 0 \\
\hline $11^{a}$ & 39 & 35 & 4 \\
\hline $12^{a}$ & 41 & 36 & 5 \\
\hline $13^{a}$ & 59 & 50 & 9 \\
\hline $14^{a}$ & 81 & 69 & 12 \\
\hline
\end{tabular}




\begin{tabular}{|c|c|c|c|}
\hline $15^{\mathrm{a}}$ & 25 & 25 & 0 \\
\hline TOTAL & 629 & 565 & 64 \\
\hline
\end{tabular}

Fonte: Gerência de Gestão Compartilhada -GEGEC/SEE-AL, 2014

É necessário problematizar quais as causas da presença de indicação dentro da gestão democrática nas escolas da rede pública estadual de ensino de Alagoas. Por que não há professores candidatando-se em tantas escolas? Por que a escola opta pela indicação? Qual a opinião dos professores, seguimento do Conselho Escolar, apto à candidatura, sobre a indicação? Como a comunidade escolar opina sobre essa realidade? As questões que nortearam a pesquisa, nos causando estranhamento, nos levaram a verificar quais os motivos de resistência dos professores em participar ativamente da gestão da escola, por meio do processo democrático de eleição direta.

\section{INDICAÇÃO DE GESTOR DENTRO DO PROCESSO DEMOCRÁTICO: O que dizem os sujeitos}

A $6^{a}$ Coordenadoria Regional de Educação (CRE) está localizada no sertão do Estado de Alagoas e é responsável por um contingente de 19 (dezenove) escolas que ofertam o ensino fundamental e médio distribuídas em 9 (nove) municípios do sertão alagoano.

Segundo dados da Unidade Regional de Desenvolvimento da Gestão das Unidades de Ensino, unidade responsável por encaminhar o processo de eleição para gestor escolar e Conselho Escolar da $6^{a}$ CRE, em 2014, foram deferidos 9 (nove) processos de substituição de gestor escolar. Desses 9 (nove) processos, 4 (quatro) foram de substituição interina por afastamento médico, em que decorrido o período de licença, o gestor retorna e 5 (cinco) foram substituições para cumprimento do mandato.

Com o objetivo de compreender os motivos pelos quais no ano de 2013, 3 (três) escolas da rede estadual de educação de Alagoas, pertencentes a $6^{a}$ CRE não passaram pelo processo de eleição, foram 
realizadas entrevistas com o intuito de verificar, nas vozes dos sujeitos, a materialização da concepção de gestão democrática.

O critério de seleção das 3 (três) escolas da $6^{a}$ CRE deu-se, pelo fato de que, no ano de 2013, não passaram pelo processo de eleição para escolha do gestor escolar. Sendo assim, para compor o quadro de sujeitos que poderiam oferecer elementos para análises de tais concepções, fizeram parte da entrevista 5 (cinco) gestores indicados para as escolas sem eleição (visto que 3 são gestores gerais e 2 são gestores adjuntos de acordo com a tipificação das escolas, ver anexo 1), 3 (três) professores que em outros períodos também tinham sido gestores, 3 (três) pais, 3 (três) alunos e 3 (três) funcionários membros do Conselho Escolar.

Para chegar à compreensão dos motivos pelos quais os professores não se candidataram à função de gestor escolar nas escolas lócus da pesquisa, fez-se necessário analisar, através de seus discursos, qual concepção de gestão democrática eles acreditam e defendem, partindo do conceito de democracia e participação como elementos de construção de uma gestão democrática vivenciada por todos os segmentos da escola, e quais as experiências que eles têm, na escola, de ações e atitudes democráticas.

Com isso, para alargar a compreensão desses motivos, foi necessário dialogar com os demais representantes do Conselho Escolar para que se pudesse verificar a concepção de democracia, participação e gestão apresentada por cada membro.

Ao analisar a concepção dos sujeitos sobre democracia, participação e autonomia, é importante perceber que as respostas e as posturas desses sujeitos foram dadas de acordo com diversos fatores.

O lugar que cada sujeito ocupa dentro da escola influenciou na sua forma de ver a escola e de posicionar-se diante dela. A fala do gestor ou do professor diferenciava muito da fala do auxiliar de limpeza ou do pai de aluno, o nível de escolaridade de cada sujeito também interferiu e 
determinou seu posicionamento em relação a sua percepção sobre as ações da escola, os conceitos questionados e o próprio cotidiano da escola.

O segmento aluno foi o que mais revelou curiosidade, pois mesmo vivenciando a rotina da escola, desconhecia muitas decisões e até o andamento das ações. Por exemplo, um aluno de uma escola entrevistada, mesmo sendo membro do Conselho Escolar, não sabia que a gestora adjunta tinha pedido exoneração e outra havia sido indicada. De acordo com o aluno, o motivo de desconhecer tal fato demandava da total ausência da gestora no horário noturno em que ele estudava.

\section{A concepção de democracia dos sujeitos da escola}

Quando os sujeitos falam em democracia, reportam-se também, a situações vividas pelo país durante o período militar e associam o fato da democracia estar relacionada com a participação e com a escolha dos governantes.

Aprender a participar e não simplesmente executar as ações que são propostas pela gestão da escola, é acima de tudo, participar da elaboração das ações, opinar sobre a necessidade ou não de tais ações ou de tais investimentos, por isso que Prado (2012) insiste em falar sobre a necessidade de aprender a participar como forma de configuração de uma gestão, de fato, democrática.

Assim, para poder compreender qual a concepção de gestão democrática dos sujeitos da pesquisa, foi necessário questioná-los sobre o conceito de democracia, e se, a partir desse conceito, poderia ser feita a relação de similaridade dos conceitos de democracia e participação ou se para os sujeitos são processos distintos e se esses conceitos delineiam o que seria democracia no ambiente escolar, sinalizando para a existência ou não de democracia na escola.

Quando o sujeito narra, apropria-se de um tipo de Formação Discursiva - FD de acordo com sua crença e na Formação Ideológica - FI assumida ou incentivada. O sujeito apropria-se do interdiscurso com base na 
formação ideológica e cria o discurso revelando a formação discursiva que está presente na narrativa. Detalhando esse conceito, Melo (2011, p. 34), explica que

"ao formular o conceito de Formações Ideológicas, Pêcheux discute os conflitos que se manifestam nas diversas posições de classe em uma determinada formação social, questionando a relação entre discurso e ideologia".

Quando questionados sobre a concepção de democracia, a resposta dos sujeitos baseava-se nos elementos descritos anteriormente sobre as variáveis de interferência das respostas como, o lugar de onde o sujeito está falando, o nível de escolaridade, a relação de trabalho estabelecida na escola, ou seja, as condições em que o discurso foi construído. Cada resposta revelava o posicionamento daquele sujeito referente ao que seria ou não democracia e se há ou não democracia ou manifestações democráticas na escola, como afirmaram alguns entrevistados.

Em algumas falas, os sujeitos partiam do conceito contrário, ou seja, diziam o que não seria democracia para inserir, em seus discursos, o que poderia ser democracia, visto que os sujeitos produzem os significados com base em suas experiências, se experimentam ou não a democracia no espaço escolar. Partiram, assim, dessa vivência para elaborar seus significados. O quadro abaixo apresenta as narrativas dos sujeitos da escola sobre a concepção de democracia.

Quadro 2: Recorte das narrativas dos participantes sobre a concepção de democracia no espaço escolar

\begin{tabular}{|c|c|l|l|}
\hline ESC & $\mathbf{N}^{\mathbf{0}}$ & \multicolumn{1}{|c|}{ NARRATIVAS } & \multicolumn{1}{c|}{ SENTIDO INFERIDO } \\
\hline $\mathbf{1}$ & $\begin{array}{l}\text { A democracia é só demagogia, porque vamos } \\
\text { supor, principalmente começando lá de cima da } \\
\text { indicação para a eleição [...] (Gestora). }\end{array}$ & $\begin{array}{l}\text { Apresenta descrença na } \\
\text { existência de democracia }\end{array}$ \\
\cline { 2 - 4 } & $\begin{array}{l}\text { É a questão de dar vez e voz a todos } \\
\text { (Coordenadora Pedagógica). }\end{array}$ & $\begin{array}{l}\text { Discurso construído com } \\
\text { base em um discurso } \\
\text { anterior }\end{array}$ \\
\hline $\mathbf{3}$ & $\begin{array}{l}\text { É você opinar, contribuir, assim, na escola. Opinar } \\
\text { todos os segmentos [...] (Funcionário). }\end{array}$ & $\begin{array}{l}\text { Sentimento de classe ao } \\
\text { estender para todos os } \\
\text { segmentos a opinião }\end{array}$ \\
\hline $\mathbf{4}$ & $\begin{array}{l}\text { É aquilo que tanto você como o outro possa optar, } \\
\text { falar, é a gente juntar numa questão só [..] (Mãe). }\end{array}$ & $\begin{array}{l}\text { Exclui-se do direito de } \\
\text { opinar }\end{array}$ \\
\hline
\end{tabular}




\begin{tabular}{|l|l|l|l|}
\hline $\mathbf{5}$ & $\begin{array}{l}\text { É a gente saber lidar com a responsabilidade que } \\
\text { a gente toma pra gente de uma maneira correta } \\
\text { (Aluno). }\end{array}$ & $\begin{array}{l}\text { A democracia é algo } \\
\text { imposto para ser } \\
\text { executado como } \\
\text { responsabilidade }\end{array}$ \\
\hline
\end{tabular}

Fonte: dados da pesquisa (2015)

Nas narrativas descritas nas entrevistas, buscou-se ver, não apenas a linguagem que é utilizada para a construção dos textos, mas também, a enunciação, o sentido que está expresso ou implícito nas vozes dos sujeitos, pois segundo Mari (2000, p. 17),

O discurso materializa formas de vida numa sociedade: entendê-lo nas circunstâncias mais diversas significa compreender o que somos, isto é, conhecer um pouco sobre aquele que o produz, ou sobre o que é objeto dessa produção; significa também, compreender como nos conduzimos na sociedade e como a percebemos.

Pode-se observar que a linguagem utilizada pelos sujeitos para descrever o termo democracia parte de um discurso outrora construído, pelo fato de a maioria usar os termos voto e liberdade para designar democracia. Paterman e Macpherson citados por Cervi (2013, p. 106) "criticam as democracias que reduzem o povo a um corpo eleitor", não é só votar, é participar, no entanto, é necessário condições para a sociedade poder participar.

De acordo com Silva (2003 p. 12),

"a facilidade com que o discurso democrático molda-se ao contexto das relações sociais e é encapada por distintas corrente políticas [...] dificultam a tarefa de identificar as diferenças entre as suas variantes".

Logo, entende-se que o conceito de democracia atribuído por cada sujeito decorre das relações que são estabelecidas na escola e das vivências de cada um. No funcionamento dos discursos materializados nas narrativas transcritas, pode ser percebido o "efeito de sentido" (PÊCHEUX, 1995, p. 99) que cada narrativa promove diante do lugar em que o sujeito fala. Democracia para a gestora não é a mesma coisa que democracia para a mãe, por exemplo. 
Sendo assim, os trechos das narrativas transcritas abaixo demonstram a aproximação e o distanciamento entre os conceitos, sendo reflexo da vivência de cada entrevistado, apresentando a interferência das formações ideológicas em seus sentidos.

Questionado sobre o que seria democracia, o funcionário auxiliar de serviços diversos apresentou a seguinte concepção:

Democracia pra seguir ao pé da letra, eu acho que não existe não. Por exemplo, o voto. Se você vai votar porque é obrigado a votar, que democracia é essa? Se você está votando por livre e espontânea vontade, está tendo uma democracia. Agora se você é obrigado, eu já não acho que é democracia, não. Eu acho que tem democracia na escola porque foi escolhido. O que seria democracia? É você opinar, contribuir, assim na escol. Opinar todos os segmentos, seja pai, seja mãe, seja aluno, seja professor, todos devem estar em conjunto pra resolver algumas situações. Aí eu acho que a democracia deva ser isso (funcionário).

A apreensão que o sujeito tem sobre a noção de democracia foi explicitada através de exemplos, porque tem mais sentido quando parte do que pode demonstrar na prática cotidiana, para depois ater-se ao conceito teórico do que seria democracia.

Os sujeitos entrevistados utilizam como argumento explicativo o que Fiorin (2000) chama de ilustração, ou seja, o narrador apresenta o início de um conceito geral da temática central e, logo em seguida, usa exemplos como argumento para comprovar o conceito outrora apresentado. Exemplo disso é quando o funcionário da escola, depois de iniciar sua explicação, insere na narrativa a frase, se você vai votar porque é obrigado a votar, que democracia é essa?

O sujeito parte do conceito de democracia explicando o que não seria democracia, que, nesse caso, associa à obrigatoriedade do voto em eleições partidárias, visto que a obrigatoriedade não existe na eleição para gestor escolar. E associa democracia escolar ao fato do gestor escolar ser escolhido pela comunidade.

Acrescenta ainda, ao seu conceito o ato de dar opinião como sendo democracia. Torna-se superficial atribuir à democracia o simples ato de dar opinião sem analisar se a opinião foi aceita ou não, se ela foi motivada ou 
simbólica, se foi consciente ou reprodução de outra opinião, apenas restringe-se a sim ou não, sem questionamentos, sem acompanhamento, sem conhecimento, sem avaliação, sem continuidade. Dar opinião simplesmente não garante a existência da democracia.

É necessário perceber na narrativa descrita acima, que, para o sujeito, a ausência de obrigatoriedade do voto na escola não elimina a presença do autoritarismo nas práticas escolares.

A eleição não consegue eliminar o autoritarismo que vem arraigado de séculos de história. Muitos gestores defendem, em seus discursos, a existência de democracia na escola, mas suas práticas revelam o contrário, como o confronto existente entre os discursos da gestora e a coordenadora pedagógica da mesma escola.

A concepção da gestora mostra-se de forma a caracterizar sua prática no ambiente escolar, pois a partir do momento que ela afirma não existir democracia, sua prática também se embasa nessa mesma afirmação.

A questão da democracia, a gente sempre começa a ver que é muito complicado. A gente que vive num mundo democrático já começa a ver que não tem. A democracia é só demagogia, porque vamos supor, principalmente começando lá de cima, da indicação para a eleição, não tem democracia. Mas a questão da democracia não tenho problema não, no relacionamento com todos, não tem a questão de impor, cada um tem suas obrigações, você sabe muito bem o que tem que cumprir (gestora).

A gestora apropria-se de uma formação discursiva conservadora e revela, em seu discurso, que a democracia será exercida se todos souberem qual seu lugar e suas obrigações. Nesse caso, "as palavras, expressões e proposições assumirão sentidos diferentes conforme as formações discursivas nas quais se inscreveram" (MELO 2011, p. 205), visto que para Pêcheux (1997, p.162),

O próprio de toda formação discursiva é dissimular, na transparência do sentido que nela se forma, a objetividade material contraditória do interdiscurso, que determina essa formação discursiva como tal, objetividade material de que "algo fala" (ça parle) sempre "antes, em outro lugar e independente", isto é, sob a dominação do complexo das informações ideológicas. 
Adotando a discussão proposta por Bobbio (1986, p. 79) sobre os interesses em jogo de cada sujeito, afirma que "os homens movem-se apenas porque têm interesses, maiores ou menores e variáveis conforme as condições e as ambições, devendo cada um proteger os seus próprios e defendê-los [...]".

Na democracia contemporânea, "o povo é condenado à quase passividade. Exerce sua 'soberania' de tempos em tempos, em momento de eleição [...] limita-se a escolher entre as opções que se são apresentadas por grupos organizados" (MIGUEL, 2002, p. 485). Sendo assim, a sociedade depara-se com uma democracia em que a manipulação tornou-se a arma das elites nas conquistas de seus próprios interesses.

Miguel (2002) continua a afirmar a impossibilidade de haver democracia enquanto existirem desigualdades sociais e políticas e a desigualdade ser caracterizada pelo fato de uma minoria dominar e uma maioria deixar-se dominar. Essa maioria permite dominar, contradizendo o que o senso comum afirma: a maioria é forte, porque a própria elite consegue, através de seus aparelhos de reprodução, ensinar um povo a ser passivo e manipulável.

O quadro abaixo apresenta os percentuais das respostas ao questionamento sobre a existência ou não de democracia na escola e o percentual de comprometimento dos membros da comunidade escolar com a gestão da escola.

Quadro 3: Percentual de respostas dos entrevistados para a pergunta sobre a existência ou não de democracia na escola

\begin{tabular}{|c|c|c|c|}
\hline Sim & Não & $\begin{array}{c}\text { Existe } \\
\text { parcialmente }\end{array}$ & Não respondeu \\
\hline $31,25 \%$ & $18,75 \%$ & $43,75 \%$ & $6,25 \%$ \\
\hline
\end{tabular}

Fonte: Dados da pesquisa (2015)

A maioria dos entrevistados, em seus discursos, criou o conceito de democracia parcial, como se pudesse existir momentos de democracia e momentos sem democracia dentro do espaço escolar. Não pode existir democracia parcial em nenhum lugar, porque de acordo com Ghanem 
(2004, p. 22), "a democracia é uma cultura e não somente um conjunto de garantias institucionais [...]".

A democracia como cultura deve ser vivenciada por todos e em todos os momentos, não pode ser fragmentada em pequenos gestos que acontecem na escola, é a forma como a escola organiza sua vivência, a definição do seu projeto de escola que no dia a dia vai dizer se a escola é democrática ou não.

É importante perceber que existe um percentual de sujeitos que não quis responder a pergunta. No entanto, na Análise do Discurso - AD, não responder ou o silenciar é uma resposta, porque parte do posicionamento ideológico do sujeito, pois, segundo Orlandi (1995, p.13), o silêncio também tem sentido, "o sentido não para, ele muda de caminho".

A postura de ficar em silêncio, diante do não querer posicionar-se, referente a afirmar implicitamente que não há democracia na escola a qual pertence, a análise do discurso interpreta como ainda resquício de um período militar em que, na escola, era ensinada "a cultura da obediência" (PRADO, 2012, p. 36). Rompe com o senso comum de considerar "quem cala' sempre está consentindo e nem sempre é assim. Muitas coisas não podem ser ditas porque forças contrárias não permitem que elas sejam ditas. Orlandi (1995, p. 17) afirma que "O funcionamento do silêncio atesta o movimento do discurso que se faz na contradição entre 'um' e o 'múltiplo', entre o mesmo e o diferente, entre a paráfrase e a polissemia".

Grande parte dos sujeitos entrevistados não se sentiu à vontade para tratar de temas que fossem referentes à prática gestora, muitos sem o domínio de conceitos como participação, autonomia e gestão democrática mostravam desconhecimento da realidade escolar.

Os sujeitos, ao construírem o conceito de democracia, perpassam também pelo conceito de participação, visto que não existe democracia sem participação (CERVI, 2013). Destarte, é necessário analisar, nos discursos, qual a concepção de participação que a comunidade escolar apresenta o que será tratado a seguir. 


\section{A concepção de participação dos sujeitos da escola}

A participação da comunidade escolar reforça a institucionalização da democracia e afasta as práticas de autoritarismo e de clientelismo presente em períodos em que a gestão da escola ainda não era democrática (LÜCK, 2005).

Nessa direção, os sujeitos foram questionados sobre o que eles entendem por participação e como eles vêem a participação deles na escola. Questionada sobre a participação do Conselho na escola, o gestor de uma das escolas afirmou que:

Participar periodicamente convocados para as reuniões extraordinárias e ordinárias, através de convocação pelo edital e posto assim, e que participa cem por cento não participa, certas horas nós conseguimos [...] certas horas não, mas temos aqueles que são atuantes, são aqueles que acompanham as ações da escola, não é cem por cento, mas a gente sabe que está longe de ser, mas o caminho é esse.

Ser atuante é acompanhar as ações da escola segundo o gestor, ele não fala em elaboração, planejamento, discussões prévias, estudos dirigidos, formações como elementos característicos da participação. Diante disso, é necessário analisar os discursos dos sujeitos para compreender qual a concepção de participação que existe na escola. O quadro 4 apresenta, de forma sistemática, a concepção de participação em níveis de frequência citado pelos entrevistados nos discursos:

Quadro 4: Análise dos discursos dos entrevistados sobre o tema participação

\begin{tabular}{|l|c|}
\hline \multicolumn{1}{|c|}{ Categorias } & Frequência \\
\hline Motivos referentes à execução de tarefas & $47 \%$ \\
\hline Motivos referentes a dar opiniões & $47 \%$ \\
\hline Motivos referentes a planejamento & $6 \%$ \\
\hline Motivos referentes à avaliação & $0 \%$ \\
\hline
\end{tabular}

Fonte: Dados da pesquisa (2015)

De acordo com o quadro, a minoria acredita que a participação deve ter início desde o planejamento, passando para a execução e 
finalizando com a avaliação que dá respaldo para novamente planejar. Nenhum dos sujeitos sinaliza para a participação como avaliação.

Segundo Lück (2005, p. 17), "sob a designação de participação, muitas experiências são promovidas, várias das quais, no entanto, apresentam, algumas vezes, resultados mais negativos do que positivos, do ponto de vista do compromisso das pessoas envolvidas".

Dentro de uma gestão efetivamente democrática em que a participação é o elemento materializador da democracia no espaço escolar, Lück (2005, p. 17) destaca que,

[...] os funcionários são envolvidos no estabelecimento de objetivos, na solução de problemas, na tomada de decisão, no estabelecimento e manutenção de padrões de desempenho e na garantia de que sua organização está atendendo adequadamente às necessidades das pessoas a quem os serviços da organização se destinam.

Assim, para que os membros da comunidade escolar desejem participar, eles precisam saber qual a função social da escola na comunidade, conhecer o seu funcionamento e, com autonomia, poder participar desde a elaboração do projeto da escola até sua avaliação, fazer valer seu voto, sua voz e sua vez na organização escolar.

\section{A concepção de autonomia dos sujeitos da escola}

A concepção de autonomia expressa pelos sujeitos trouxe subsídios para analisar se a escola considera-se autônoma ou não, se o gestor também considera que a escola tem autonomia e se professores e demais membros do Conselho Escolar poderiam identificar a autonomia nas ações desenvolvidas pela escola.

A pesquisa adotou o conceito de autonomia de Barroso (1998, p. 17) que afirma ser a autonomia "um campo de forças, onde se confrontam e equilibram diferentes detentores de influência (externa e interna) dos quais se destacam governo, a administração, professores, alunos, pais e outros membros da sociedade local". 
Quando questionados sobre o que seria autonomia, $34 \%$ dos entrevistados disseram que não sabiam responder à pergunta, $6 \%$ não responderam.

De acordo com o discurso da coordenadora pedagógica, não existe autonomia porque a gente é obrigado a fazer o que a SEE (Secretaria de Estado da Educação) manda, finge que existe democracia que nunca existiu. Ela associa a obrigatoriedade do cumprimento do Plano de Ação elaborado pela SEE/AL como uma forma de retirada da autonomia da escola.

O discurso da gestora é coerente com o discurso da coordenadora pedagógica em afirmar que autonomia que existe nas escolas é simplesmente uma falsa autonomia, porque não vê a autonomia da escola.

Segundo o discurso do gestor, autonomia é você fazer sem perguntar a ninguém. Não tenho autonomia, a gente faz as coisas com certa limitação, muita coisa ainda ta vinculada ao Conselho Escolar, a gente não tem autonomia plena, só tem autonomia parcial.

O gestor posicionou-se de acordo com suas convicções, como ele foi indicado para o provimento da função de gestor nesta escola, ele acredita que, individualmente, é mais fácil trabalhar na escola do que precisar de um Conselho Escolar apenas para figurar na sua gestão, comparecendo às reuniões quando solicitado e assinando os registros que precisam ser assinados.

De acordo com Pêcheux (1995, p. 171), "a tomada de posição não é, de modo algum, concebível como um 'ato originário' do sujeito falante: ela deve, ao contrário, ser compreendida como o efeito da forma-sujeito". O sujeito apropria-se de discursos externos para construir o seu e acaba pensando que seu posicionamento partiu de si e não de outras experiências e outros dizeres que ele ouviu ou viveu em outros períodos.

Os sujeitos, ao construírem em seus discursos o conceito de autonomia, apropriam-se de dizeres anteriores sobre autonomia ser sinônimo de falta de 
limites, tão celebrado no senso comum. Falam de uma autonomia arbitrária, sem ligação com nenhuma conjuntura.

A escola também não precisa de uma autonomia sem controle e sem limites. De acordo com Paro (2001, p. 115),

[...] gerir os recursos com autonomia não implica utilizá-los apenas da forma que professores e diretores consideram mais conveniente. Significa que a partir de diretrizes gerais traçadas pelo sistema cada unidade escolar imprime em sua gestão uma forma mais adequada a suas peculiaridades.

Sendo assim, grande parte dos discursos dos sujeitos sobre autonomia aponta para a existência, na escola, de uma prática do individualismo a serviço do atendimento a certas conveniências, que nem sempre atendem às especificidades da escola.

A luta não deve ser pela implantação de uma autonomia individualizada nas unidades escolares "o que está em causa não é conceder maior ou menor autonomia às escolas, mas sim reconhecer a autonomia da escola como um valor intrínseco a sua organização, e utilizar essa autonomia em benefício das aprendizagens dos alunos" (BARROSO, 1998, p. 18).

\section{Motivos da presença de indicação na eleição de gestor escolar em 2013 na $6^{a}$ Coordenadoria Regional de Educação}

Cervi (2013, p. 109), ao falar sobre o processo de democratização do país, afirma que "a década de 1980 também foi um tempo de crítica à ditadura militar e a tudo que traz seus resquícios. Dentre as críticas às escolas, destacam-se: o autoritarismo, o tecnicismo, os especialistas, a falta de liberdade, de autonomia, de participação e de democracia".

A gestão democrática da educação, bem como a gestão democrática das unidades escolares, em que a sociedade civil participa das decisões como um todo em nível macro através da elaboração dos planos destinados à educação nacional e micro referente às ações desenvolvidas 
na escola, passa pela luta em prol da democratização da educação no país.

De acordo com Lima (1998, p. 252)

A expressão gestão democrática é por natureza plurissignificativa, seja ao nível das representações sociais e dos discursos de todo tipo (político, administrativo, pedagógico, e até mesmo acadêmico), seja ao nível das práticas. O nosso ponto de vista é o de que, na prática, tal ambigüidade e oscilação semântica têm sido aproveitadas freqüentemente por diferentes forças e sectores [...], servindo diferentes objectivos, interesses e estratégias.

Sendo assim, nem toda prática gestora pode ser considerada democrática como afirmam os sujeitos (18,75\%), podendo ser uma democracia parcial $(43,75 \%)$.

O perfil de um gestor democrático não pode centralizar as decisões da escola, é necessário que ele transfira "a autoridade e a responsabilidade pela gestão de um bem público para um grupo diretamente envolvido no trabalho [...]" (GUTIERREZ; CATANI, 1998, p. 63).

Segundo relatos, a comunidade escolar considera como um gestor democrático uma pessoa que:

\section{[...] traga benefícios para a escola (aluno);}

[...] não veja os problemas (mãe);

[...] com bons conhecimentos, mente aberta para mudanças, pra ouvir a opinião do outros também, não ser a opinião de um que valha, tem que ter liderança, ser um bom líder, saber gerir (funcionário);

[...] participativo, deixar aberto ao publico, à comunidade escolar a discussão para que seja montado o plano estratégico de ação (gestor).

A comunidade escolar entende, por sua vez, e comunga da mesma ideia de que o ponto forte no perfil do gestor escolar seja a abertura ao diálogo, à participação de todos. Sem esses elementos, a gestão da escola limitar-se-á a um modelo anteriormente criticado em que, na figura do gestor, eram centralizadas todas as ações da escola e os demais membros resumiam-se a meros executores de tais ações.

Segundo Paro (2001, p. 73), "essa maior possibilidade de opinar, características de um ambiente mais democrático, acaba levando os sujeitos envolvidos na educação escolar a uma postura mais participativa." 
Ademais, o gestor deve oportunizar, no espaço escolar, situações que possa favorecer a participação.

Dos sujeitos que responderam à questão sobre gestão democrática, 1 (um) não respondeu e 1 (um) disse que não sabia dizer o que era gestão. Os demais associam a concepção de gestão democrática à existência de participação em que todos participem e não apenas o gestor.

Questionados sobre o fato de haver indicação de professor dentro de um processo democrático, $80 \%$ disseram que não concordam e $20 \%$ concordam com a indicação. Visto que, a legislação estadual é clara ao afirmar que só pode candidatar-se à função de gestor escolar o professor que exercer função na rede estadual, não abrindo espaço para que outros funcionários da escola, que desenvolvem a função docente em outra rede, possam ter o direito de lançar-se à candidatura.

A falta de condições de trabalho, carga horária reduzida e baixa gratificação pela função, foram apontadas, por parte dos entrevistados, como motivo que afastam os professores da função de gestor escolar.

Os professores acreditam que as dificuldades enfrentadas pelo gestor e as condições de trabalho em que o estado de Alagoas submete-os, são os elementos causadores da falta de professores para candidatar-se à função de gestor escolar.

É preciso condições suficientes para que o gestor, juntamente com o Conselho Escolar, possa gerir os recursos da escola, organizar as ações através do projeto político pedagógico e tentar fazer com que a gestão seja, de fato, democrática.

Segundo o discurso de um funcionário pra ser diretor na rede estadual de Alagoas tem que ter muita coragem pelas condições que thes são ofertadas, retrata os motivos pelos quais os professores recusam-se à candidatura de gestor escolar na rede estadual de Alagoas.

Dos 5 (cinco) gestores indicados para assumir a função, 60\% atribuíram ao fato de aceitar desafios de mudar a realidade como sendo uma das motivações que os levaram a aceitar a função, outro motivador foi a 
questão de garantias de permutas entre as redes de ensino (20\%), o apadrinhamento 3 que perdura até os dias atuais, e aproveitamento da experiência na gestão de outra escola (20\%), por motivo de não poder ser candidato por ter sido eleito para dois mandatos.

Os discursos dos gestores indicados revelam que os interesses pessoais moldam a decisão de aceitar a função de gestor escolar, mesmo sabendo que o desafio é grande, diante da realidade das escolas da rede pública estadual de Alagoas.

A gestão da escola em Alagoas acaba, muitas vezes, por produzir frustrações nos gestores e professores, como também nos demais funcionários e alunos, já que a vontade de fazer um trabalho de qualidade esbarra nas limitações que são produzidas pela carência da realidade alagoana. A escola, em grande parte, fica privada de realizar um trabalho de emancipação intelectual, visto que a falta de professores compromete a qualidade da educação.

A indicação retira do sujeito o direito de poder decidir e escolher por quem vai, juntamente com o Conselho Escolar, gerir a escola como instrumento de garantia da existência de democracia através da participação.

É necessário que essa realidade seja revertida por parte do governo, já que é de sua competência, para que a indicação de professores a função de gestor escolar não esteja presente no Estado de Alagoas como algo normal, visto que, a luta pela implantação da gestão democrática no estado não pode retroceder por questões de falta de professor e péssimas condições de trabalho.

\section{CONCLUSÃO}

Com o objetivo de analisar, a partir dos discursos dos sujeitos, por que os professores da rede estadual de ensino de Alagoas não se candidataram

\footnotetext{
${ }^{3}$ Cf. VERÇOSA, E. de G. Cultura e Educação nas Alagoas: história, histórias. 4 ed. Maceió: EDUFAL, 2006.
} 
em três escolas da $6^{a}$ Coordenadoria Regional de Educação, as análises realizadas possibilitaram observar que o funcionamento dos discursos atendia segundo Pêcheux (1995), a uma formação ideológica específica que se materializava através da formação discursiva pelos discursos que eram inferidos sobre determinadas questões.

Uma gestão democrática com base na participação, em que a comunidade representada no Conselho Escolar possa participar de forma consciente desde a elaboração do projeto da escola, passando pela execução e finalizando com a avaliação de toda a sistemática de trabalho construído por todos e para todos, ainda é uma realidade distante de ser executada em grande parte das escolas da rede estadual de Alagoas.

As condições que são ofertadas na rede estadual de Alagoas, em que a escolas, na grande maioria, precisam de ampliação e reforma, o quadro de professores e funcionários a cada ano continua mais escasso, ano letivo sendo concluído com falta de professores em algumas disciplinas, não motivam os professores a candidatarem-se à função de gestor escolar para gerir uma escola dentro de um cenário de falta de recursos para administrar.

A problemática que envolve a situação da presença da indicação de professores para o provimento do cargo de gestor escolar perpassa pela falta de condições existentes na rede estadual de ensino de Alagoas. A precariedade presente na rede poderá contribuir para $\circ$ aumento da indicação, caso não seja revista a legislação estadual para a eleição de gestor.

Assim, faz-se necessário recolher elementos que dêem possibilidade ao aprofundamento da discussão com o intuito de contribuir não apenas com um projeto micro, mas que possa ser a vazão para o entendimento e posicionamento em nível macro dessa problemática que não deve ser apenas um fenômeno em Alagoas. 


\section{REFERÊNCIAS}

ALAGOAS. Lei n 6.152 de 11 de maio de 2000. Institui eleições diretas para diretores gerais e adjuntos nas escolas de educação básica da rede pública estadual. Diário Oficial do Estado de Alagoas. Maceió, 2000.

ALAGOAS. Lei $n^{\circ} 6.628$ de 21 de outubro de 2005. Institui novas regras para a gestão na rede estadual de ensino. Diário Oficial do Estado de Alagoas. Maceió, 24 de outubro de 2005.

BARROSO, J. O reforço da autonomia das escolas e a flexibilização da gestão escolar em Portugal. In: FERREIRA, N. S. C. (Org.). Gestão Democrática da Educação: atuais tendências, novos desafios. 3. ed. São Paulo: Cortez, 1998.

BOBBIO, N. O futuro da democracia: uma defesa das regras do jogo. Traduação de Marcos Aurélio Nogueira. 6. Ed. Rio de Janeiro: Paz e Terra, 1986.

CERVI, G. Política de gestão escolar na sociedade de controle. Rio de Janeiro: Achiamé, 2013.

COSTA, J. C. Instrução pública e instituições culturais de Alagoas. Maceió: Imprensa Oficial, 1931.

DOURADO, L. F. Democratização da escola: eleições de diretores, um caminho?(1990), 176 f. Dissertação (Mestrado em Educação Escolar Brasileira) Universidade Federal de Goiás, Goiânia, 1990.

DOURADO, L. F. A escolha de dirigentes escolares: políticas e gestão da educação no Brasil. In: FERREIRA, N. S. C. (org.). Gestão democrática da Educação: atuais tendências, novos desafios. São Paulo: Cortez, 1998.

DOURADO, L. F.; COSTA, M. Escolha de dirigentes escolares no Brasil: relatório final de pesquisa. Brasilia: ANPAE, 1998.

FIORIN, J. L. Elementos de análise do discurso. 9. Ed. São Paulo: Contexto, 2000.

GHANEM, E. Educação escolar e democracia no Brasil. Belo Horizonte: Autêntica, 2004.

GUTIERREZ, G. L. CATANI, A. M. Participação e gestão escolar: conceitos e potencialidades. In: FERREIRA, N. S. C. (Org.). Gestão Democrática da Educação: atuais tendências, novos desafios. 3. ed. São Paulo: Cortez, 1998.

LIMA, L. C. A escola como organização e a participação na organização escolar. 2 ed. Braga: Centro de estudos em educação e psicologia, Universidade do Minho, 1998.

LIMA, V. B. A gestão democrática sob a égide da legislação: um olhar sobre a realidade do estado do Ceará. In: PRADO, E. C.; DIÓGENES, E. M. N. (orgs.). Avaliação de políticas públicas: interface entre educação e gestão escolar. Maceió: EDUFAL, 2011. 
LÜCK, H. A escola participativa: o trabalho do gestor escolar. Petrópolis, RJ: Vozes, 2005.

MARI, H. A análise do discurso e ensino: a importância de se pensar o trabalho com a língua. In: MARI, H. (or.). Categorias e práticas de análise do discurso. Belo Horizonte: Núcleo de análise do discurso. FALE/UFMG, 2000.

MELO, K. M. S. Discurso, Consenso e Conflito: a (re) significação da profissão docente no Brasil. Maceió, EDUFAL, 2011.

MIGUEL, L. F. A democracia domesticada: bases antidemocráticas do pensamento democrático contemporâneo. Revista de Ciências Sociais, vol. 45, n 3, pp. 483 a 511, 2002.

ORLANDI, E. P. As formas do silêncio: no movimento dos sentidos. 3. ed. Campinas, São Paulo: Editora UNICAMP, 1995.

PARO, V. H. Escritos sobre educação. São Paulo: Xamã, 2001.

PARO, V. H. O principio da gestão democrática escolar no contexto da LDB. In: MINTO et al. Gestão, financiamento e direito à educação: análise da LDB e Constituição Federal. São Paulo: Xamã, 2001.

PARO, V. H. Eleição de diretores: a escola pública experimenta a democracia. 2. Ed. São Paulo: Xamã, 2003.

PÊCHEUX, M. Semântica e discurso: uma crítica à afirmação do óbvio. 2. ed. Campinas, SP: Editora da UNICAMP, 1995.

PÊCHEUX, M.; FUCHS, C. A propósito da Análise Automática do Discurso: atualização e perspectivas. In: Por uma Análise Automática do Discurso: uma introdução à obra de Michel Pêcheux. 3 ed. Campinas, SP: Editora da UNICAMP, 1997 (tradução de tradutores Bethania S. Mariani et al).

PRADO, E. Estágio na licenciatura em Pedagogia: gestão educacional. Petrópolis, RJ: Vozes; Maceió, AL: Edufal, 2012.

SILVA, I. G. Democracia e participação na reforma do estado. São Paulo, Cortez, 2003.

VERÇOSA, E. G. Cultura e Educação nas Alagoas: história, histórias. 4 ed. Maceió: EDUFAL, 2006.

Recebido em: Junho de 2017 Aprovado em: Outubro de 2017 